\title{
Kvėpavimo takų infekcijos esant imuniteto nepakankamumui
}

\author{
Greta Dvareckaitė, Brigita Šitkauskienè \\ LSMU MA Pulmonologijos ir imunologijos klinika
}

Reikšminiai žodžiai: kvėpavimo takų infekcijos, imuniteto nepakankamumas, imunodeficitas.

Santrauka. Straipsnyje aptariamas kvėpavimo takų infekcijų dažnumas ir pobūdis esant imuniteto nepakankamumui.

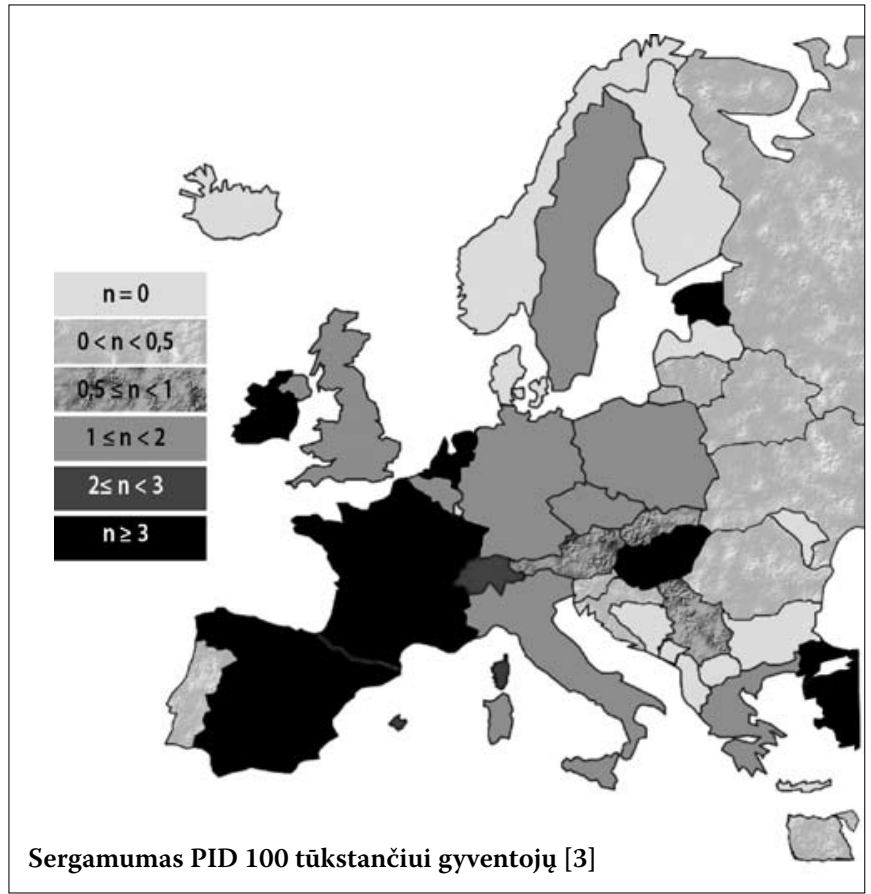

Pav. Dokumentuotas pirminio imunodeficito dažnumas Europoje
Kvėpavimo takụ infekcijos - dažnas reiškinys imunodeficito sąlygomis [1], tačiau tik nedaugelio pacientų, sergančiu kvèpavimo takų infekcinèmis ligomis, imunitetas yra nepakankamas. Straipsnyje aptariama, kada pacientui reikètu ittarti imunodeficito būklę ir kokie patogenai šiems pacientams dažniausiai sukelia kvejpavimo takụ infekcijas.

Imunodeficitas - savarankiškų ligu ar lydinčių sindromu grupė [2]. Bendras požymis - imuninès sistemos nepakankamumas. Imunodeficitas gali būti pirminis ir antrinis. Pirminis imunodeficitas (PID) - igimti imuninès sistemos pokyčiai, paprastai sukelti genetinio defekto [2]. JAV atliktu tyrimu duomenimis, PID nustatomas vienam iš 1200 gyventoju [3]. PID paplitimas Europoje, remiantis ESID (angl. European Society of Immunodeficiencies) duomenimis, pateikiamas paveiksle [3].

Antrinį imunodeficitą gali lemti įvairios priežastys. Jis pasireiškia sergant sunkiomis užsitęsusiomis infekcinèmis, piktybinèmis, autoimuninemis ligomis ir pan. [5]. Imunodeficitas skiriamas ir atsižvelgiant $i$ tai, kuri imuniteto dalis yra pažeista: humoralinis, ląstelinis, komplemento ar fagocitozès [2]. Esant imunosupresijai, pacientai tampa imlūs infekcijoms, o kvèpavimo sistemos organai yra vieni dažniausiai pažeidžiamų [6].

Nuo to, kuri imuniteto grandis pažeista, priklauso infekcijos pobūdis (lentelè).

Lentelè. Imuniteto pažeidimo pobūdis ir infekcijos tipas

\begin{tabular}{|c|c|c|c|}
\hline & Pažeistas komponentas & Pagrindinès priežastys & Pagrindiniai patogenai \\
\hline $\begin{array}{l}\text { Humoralinis } \\
\text { imunodeficitas }\end{array}$ & $\begin{array}{l}\text { B limfocitai, plazminès } \\
\text { ląstelès, antikūnai }\end{array}$ & $\begin{array}{l}\text { Pirminis humoralinis imunodeficitas } \\
\text { Dauginė mieloma } \\
\text { Lètinė limfoleukemija } \\
\text { AIDS }\end{array}$ & $\begin{array}{l}\text { Streptococcus pneumoniae, Hemophilus influenzae, Pneumo- } \\
\text { cystis jirovecii, Giardia intestinalis, Cryptosporidium parvum }\end{array}$ \\
\hline $\begin{array}{l}\text { Ląstelinis } \\
\text { imunodeficitas }\end{array}$ & T limfocitai & $\begin{array}{l}\text { Kaulų čiulpų ar kita transplantacija } \\
\text { AIDS } \\
\text { Vèžio chemoterapija } \\
\text { Limfoma } \\
\text { Gliukokortikoidai }\end{array}$ & $\begin{array}{l}\text { Viduląsteliniai patogenai, įskaitant Herpes simplex, Citome- } \\
\text { galo virusas, Ebstein-Barr virusas, Mycobacterium, Listeria, } \\
\text { grybelinės infekcijos (Candida, Cryptococcus, Pneumocystis) }\end{array}$ \\
\hline $\begin{array}{l}\text { Fagocituojančių } \\
\text { ląstelių defektas }\end{array}$ & Neutrofilai & $\begin{array}{l}\text { Leukemijos chemoterapija } \\
\text { Kaulų čiulpų transplantacija } \\
\text { Lètinė granulomatozinė liga }\end{array}$ & $\begin{array}{l}\text { Enterobacteriaceae, Streptococcus, Pseudomonas aeruginosa, } \\
\text { Enterococcus, Candida, Aspergillus }\end{array}$ \\
\hline $\begin{array}{l}\text { Komplemento } \\
\text { trūkumas }\end{array}$ & Komplemento sistema & Igimtas imunodeficitas & Neisseria, Streptococcus pneumoniae \\
\hline
\end{tabular}


Neutropenija, besitęsianti ilgiau kaip septynias dienas, siejama su grybelinès infekcijos rizika, ypač invazine aspergilioze [6]. Ląstelinio imuniteto sutrikimai yra susiję su tuberkuliozès infekcija ir Pneumocystis jiroveci sukelta pneumonija [6].

\section{KADA, ESANT KVĖPAVIMO TAKUৃ INFEKCIJAI, REIKĖTŲ İTARTI IMUNODEFICITĄ}

Suaugusiesiems pasikartojančias kvėpavimo takų infekcines ligas dažniausiai lemia kvejpavimo takų anatominis defektas (pvz.: bronchektazès, navikai, striktūros, svetimkūniai) arba antrinè imuniteto supresija, bet PID taip pat turètų būti įtrauktas į diferencinę diagnozę. Dauguma PID būklių būna nustatomos jau kūdikystèje arba vaikystejje, nes šie pacientai dažnai hospitalizuojami dèl sunkių infekcijų ir sulètejjusio augimo bei raidos [2]. Tačiau kai kurios imunodeficito būklès, pavyzdžiui, antikūnų defektai sergant ịprastiniu kintamuoju imunodeficitu, gali likti nepastebètos iki suaugusiojo amžiaus.

Imunodeficitas turètų būti įtariamas šiais atvejais:

- Jei apatinių kvėpavimo takų infekcinès ligos kartojasi, atsparios iprastiniam gydymui arba sukeltos oportunistinių ar neiprastų patogenų [7].

- Jei pneumonija kartojasi ne toje pačioje, o vis kitoje plaučiuc dalyje; kyla neiprastų komplikacijų (pvz.: pneumocistos, ertminiai pažeidimai).

- Bendroje populiacijoje pneumonijos kartojimasis (daugiau kaip du kartus per gyvenimą) yra neiprastas reiškinys. Tokiu atveju taip pat reikètų itarti imunodeficitą [7].

Pacientai, kuriems pneumonija kartojasi tam tikroje anatominėje srityje (pvz., dešiniojoje vidurinèje skiltyje), dažniausiai turi igimtą anatominę anomaliją [7]. Jei pasikartojanti infekcija apima įvairius plaučių plotus, didesnė sisteminès ligos tikimybè (pvz.: cistinès fibrozès, vaskulito, imunodeficito). Suaugusiesiems PID turètų būti įtartas kartojantis apatinių kvėpavimo takų infekcinèms ligoms kartu su kitos lokalizacijos infekcijomis, kaip antai sinusitu ar otitu [8].

Jeffrey Modell Foundation parengè „10 perspèjamųju ženklų" klausimyną, padedantị itarti PID [4]. Šis klausimynas sukurtas siekiant didinti gydytojuc ir visuomenès budrumą PID atžvilgiu [4]. PID reikètų ịtarti šiais atvejais:

- 4 ir daugiau vidinès ausies uždegimú per metus;

- 2 ir daugiau sinusitu per metus;

- Gydant tinkamais antibiotikais, infekcija tęsiasi du ir daugiau ménesių;

- 2 ir daugiau plaučiuc uždegimų per metus;

- Sulètèjęs kūdikio augimas ir raida;

- Pasikartojantys furunkuliai, karbunkulai ar vidaus organų abscesai;

- Persistuojanti grybeliné infekcija vyresniems nei vienerių metų asmenims;

- Intraveninių antibiotikų poreikis infekcijoms gydyti;

- Dvieju ar daugiau skirtingu sukèlèjų sukeltos persistuojančios infekcijos;

- Šeiminė PID anamnezė [4].

\section{KVĖPAVIMO TAKỤ INFEKCIJOS ESANT PIRMINIAM IMUNODEFICITUI}

Kvėpavimo takai, ypač apatiniai, yra dažniausias infekcijų taikinys sergant imunodeficitu. [9]. Ilgejjant sergančių PID gyvenimo trukmei, daugejja kvejpavimo takų ligų komplikacijų: ūminių arba lètinių infekcijų, predisponuojančių piktybinių naviku formavimąsi, struktūrinius pažeidimus bei sutrikusias uždegimo reakcijas, skatinančias audinių pažeidimą (pvz.: granuliomas, plaučių fibrozę) [9]. Daugumai pacientų, sergančių imunodeficitu, kai stinga antikūnų, kartojasi ūminès ir vystosi lètinès kvėpavimo takų infekcijos, skatinančios formuotis bronchektazes [10]. Kvèpavimo takų infekcijos ir kvejpavimo funkcijos nepakankamumas yra dažniausia imunodeficito būklès pacientų ankstyvos mirties priežastis [10].

Kai PID lengvesnès formos, pacientai gali būti mažiau imlūs oportunistiniams ar neịprastiems patogenams. Jie dažniau serga sunkesnès eigos sinopulmoninėmis infekcijomis, sukeliamomis itprastų mikroorganizmų: $S$. pneumoniae, $H$. influenza arba $M$. catarhalis [10]. Pacientams, sergantiems sunkesniu PID, ypač esant pažeistiems T limfocitams arba fagocituojančių ląstelių funkcijai, oportunistinių ar neịprastų patogenų sukeliamų infekcijų rizika didesnè.

Pneumonija, sukelta Pneumocystis jirovecii, Pseudomonas, Burkholderia, Aspergillus arba citomegalo viruso, asmenims, kurių imunitetas normalus ir kurie pastaruoju metu nebuvo hospitalizuoti, pasitaiko retai [11]. Jei nustatoma, kad pneumoniją sukèlè šie mikroorganizmai, reikètų pagalvoti apie galimą imunodeficitą.

\section{KVĖPAVIMO TAKŲ INFEKCIJOS POBŪDIS PAGAL PID TIPĄ}

Humoralinio imunodeficito atveju sutrinka antikūnų gamyba, dèl to kartojasi sunkios eigos viršutinių ir apatiniuc kvėpavimo taku infekcinès ligos, sukeliamos inkapsuliuotu bakterijuc (pvz., Streptococcus pneumoniae, Haemophilus influenzae) [12]. Būdingos ir netipinių bakterijų sukeltos infekcijos [13]. Esant imunoglobulino (Ig) G poklasių nepakankamumui, dažni ir ịprastinių patogenų sukeliamos pneumonijos atvejai [14]. Sergant humoraliniu imunodeficitu, dažnai kartojasi bakterinès infekcijos: vaikystèje dažnesnis vidurinès ausies uždegimas, sinusitas, pneumonija, suaugus vidurinès ausies uždegimas pasitaiko rečiau. Šio tipo PID sergantiems pacientams dažnai pasikartojančios apatinių kvejpavimo takų infekcinès ligos skatina formuotis bronchektazes [2]. Priklausomai nuo specifinio imunodeficito, kuriuo serga pacientas, tipo skiriasi klinikinio ligos pasireiškimo laikas: pavyzdžiui, sergantiems Brutono liga, infekcijos prasideda kūdikystëje, esant ịprastiniam kintamajam imunodeficitui - antrą trečią gyvenimo dešimtmeti.

Ląstelinio imunodeficito priežastis gali būti ịvairūs genetiniai defektai, sutrikdantys T limfocitų funkciją (pvz., DiGeorge sindromas, sunkus kombinuotas imunodeficitas). Sergantys šio tipo imunodeficitu tampa imlūs virusų, pirmuonių ir grybelių infekcijoms [2]. 
Sunkus kombinuotas imunodeficitas (SKID) pasireiškia dideliu imlumu ịvairioms infekcijoms (bakterijų, virusų, grybelių). Sergant SKID, būdingos kvėpavimo takų oportunistinès infekcijos (dažniausiai sukeliamos Pneumocystis jirovecii, citomegalo viruso, adenoviruso, respiracinio sincitinio viruso, ir/ar 3 tipo paragripo viruso) ir intersticinès ligos [2]. Ligoniai paprastai miršta pirmaisiais gyvenimo metais nuo infekcijų sukeliamų komplikacijų [2].

\section{ANTRINIS IMUNODEFICITAS}

Antrinis imuniteto nepakankamumas dažnesnis nei pirminis. Ji gali sukelti ịvairios priežastys:

- Infekcija (virusinès infekcijos (ŽIV, tymų, Herpes virusai); bakterinès infekcijos (pvz., stafilokokai, streptokokai); parazitinès infekcijos (pvz., leišmaniozè)).

- Imunosupresiné terapija (citotoksinè chemoterapija; autoimuninių ligų gydymas; kaulų čiulpų abliacija prieš transplantaciją; gydymas ar profilaktika transplantanto prieš šeimininką reakcijos po kaulų čiulpų transplantacijos; atmetimo reakcijos po solidinio organo transplantacijos gydymas; imunomoduliuojamoji terapija rituksimabu, etanerceptu ir pan.).

- Piktybinès ligos (Hodžkino limfoma; lètinè limfoleukemija; dauginè mieloma; solidiniai navikai).

- Biocheminès homeostazès sutrikimai (cukrinis diabetas; inkstu funkcijos nepakankamumas; kepenų funkcijos nepakankamumas).

- Autoimuninés ligos (sisteminė raudonoji vilkligé; reumatoidinis artritas; opinis kolitas ir kt.).

- Audinių pažeidimas (periferinių arterijų liga su išemija; nudegimai; splenektomija ir pan.).

- Aplinkos žalingų veiksnių ekspozicija (spinduliuotė (jonizuojančioji, ultravioletinè), toksiniai chemikalai).

- Kitos ligos (chromosomų anomalijos (pvz., Dauno sindromas); raumenu distrofija; hemoglobinopatija; baltymų netekimas (pvz., nefrozinis sindromas).

- Kitos priežastys (neišnešiotumas; narkomanija; stresas; alogeninè kraujo transfuzija; senejjimas).

Sergančių antriniu imuniteto nepakankamumu daugèja ilgejjant gyvenimo trukmei po solidinių organų ir hematopoetinių ląstelių transplantacijų, daugejjant autoimunių sutrikimų ir plintant ŽIV/AIDS epidemijai. Imunosupresine terapija sukelia ịvairų imuninio atsako grandžių nepakankamumą, kuris yra substratas oportunistinems infekcijoms. Šiems pacientams pasireiškia padidèjęs imlumas infekcijoms, kurių virulentiškumas esant normaliam imunitetui mažas. Antriniu imunodeficitu sergantiems pacientams kvėpavimo taku infekcijos yra dažniausios [15], dažniau pasitaiko ir grybelinių plaučių infekcijų $[2,15]$.

\section{IMUNOSUPRESINE் TERAPIJA}

Imunosupresinė terapija gliukokortikoidais (GK) - itin svarbi gydant autoimunines ligas, atmetimo reakcijas po transplantacijos, bet gydymas sisteminio poveikio GK didina infekcijos riziką. GK turi platų poveikị imuninei sistemai, ypač $\mathrm{T}$ ir B limfocitų atsakui, fagocitų funkcijai.
Nepageidaujamo GK poveikio rizika priklauso nuo dozès, gydymo trukmès, gydomos ligos ir paciento bendrosios būklès. Pavyzdžiui, blogos funkcinès būklès vyresnio amžiaus pacientams imunodeficito sukeltų komplikacijų dažnumas gydant GK ir kitais imunosupresiniais vaistais yra didesnis [16].

GK nepalankiai veikia pneumonijos patogenezę, nes silpnina alveolinių makrofagų bei neutrofilų fagocitinę funkciją ir mažina uždegimo ląstelių mobilizaciją $\mathfrak{z}$ infekcijos židinị. Dèl šių priežasčių padidejja bakterinių ir grybelinių infekcijų (Pneumocystis jirovecii, Nocardia spp, Aspergillus spp) ir plaučiu pažeidimo, sukeliamo virusų (Cytomegalovirus, Varicella zoster viruso), rizika. Herpes zoster dažniau pasitaiko pacientams, vartojantiems nedideles GK dozes [16]. Tuberkuliozè dažnesnè pacientams, kuriems skiriamos vidutinès ar didelès GK dozès ilgesni laiką. Pneumocystis jirovecii sukeltas pneumonitas siejamas su nuolatiniu vidutinių ir trumpalaikiu didelių GK dozių vartojimu. Inhaliuojamieji ir išoriškai vartojami GK nèra susiję su didesne sisteminès infekcijos rizika [16].

\section{AUTOIMUNINĖS LIGOS}

Autoimuninėmis ligomis sergantys pacientai gali būti imlūs oportunistinėms infekcijoms. Dažniausios šiems pacientams yra bakterinès infekcijos, kurios siejamos su opsonizacijos ir fagocitozès sutrikimais [16]. Pagrindinę ligą lydinčios infekcijos (kvèpavimo sistemos virusinè infekcija bei po to prisidedanti bakterinè ar grybelinè infekcija) taip pat yra dažnos. Šių infekcijų sunkumas ir etiologija priklauso nuo ligos pobūdžio, jos trukmès ir gydymui skiriamos imunosupresijos intensyvumo.

Pacientams, sergantiems jungiamojo audinio ligomis, infekcijos požymius gali būti sunku atskirti nuo pirminès ligos klinikinio pasireiškimo ar gydymo toksinio poveikio.

\section{ŽIV INFEKCIJA/AIDS}

Invazinės pneumokokinès infekcijos rizika ŽIV užsikrètusiems pacientams padideja iki 50-100 kartų [17]. ŽIV užsikrètusiems pacientams, vaikystëje skiepytiems konjuguota S. pneumoniae polisacharidine vakcina, invazinès pneumokokinès infekcijos atvejai retesni, kai infekciją sukelia vakcinos serotipai, tačiau S. pneumoniae infekcijos sukeliamos nevakcininių serotipų dažnumas padidèja [17].

Bakterinès plaučių infekcijos yra itin dažnos užsikrètus ŽIV [18]. Kasmetinė rizika susirgti bakterine pneumonija ŽIV užsikrètusiems pacientams yra 5,5-29 proc., palyginti su 0,7-10 proc. neužsikrètusiems [18]. Stiprios ekonomikos šalyse bakterinių patogenų, ypač Pneumocystis jirovecii, sukeliamų ligų dažnumas sumažèjo prasidejus efektyvios antiretrovirusinès terapijos erai [18].

Bakterinès pneumonijos rizika tiesiogiai susijusi su CD4 (+) ląstelių kiekiu. ŽIV infekcija yra ir pasikartojančios pneumokokinès pneumonijos su bakteriemija rizikos veiksnys [17]. Dèl to „Centers for Disease Control and Prevention“ 1992 metais ịtraukẻ pasikartojančią bakterinę 
pneumoniją i AIDS apibrèžiančių būklių aprašą. Ūminė bakterinè pneumonija gali sumažinti CD4 (+) ląstelių kiekị. Pasikartojanti bakterinė pneumonija siejama su išliekančiu plaučių funkcijos sutrikimu ir padidejjusiu mirtingumu [19].

\section{INFEKCIJOS IR ANTRINIS IMUNODEFICITAS}

Kai kurios infekcijos gali pačios pažeisti imunini atsaką ir taip sukelti antrinị imunodeficitą [2], iš virusų (neskaitant ŽIV) - dažniausiai tymų (morbillivirus) ir Herpes virusai.

Tymų virusas yra vienintelis (be ŽIV) virusas smarkiai slopinantis organizmo imunitetą, o tai gali lemti sunkias superinfekcijas [20]. Viename retrospektyviajame klinikiniame tyrime, kuriame buvo analizuoti mirtimi pasibaigę tymų infekcijos atvejai Pietu Afrikoje, nustatyta, kad 85 proc. mirčių buvo sukeltos virusinių, bakterinių ar grybelinių plaučių infekcijų, kurios prisidejo prie tymų infekcijos [20].

Pneumonija ir laringotracheobronchitas yra vienos dažniausių tymų komplikacijų [5]. Šias komplikacijas dažnai sukelia virusai (Herpes simplex, Cytomegalovirus, Parainfluenza, Adenovirus, Coxsackie ir respiracinis sincitinis virusas) ar tipinès visuomenèje igytą pneumonija sukeliančios bakterijos [20]. Tymų sukeliamas imunodeficitas išsivysto dèl T limfocitų pažeidimo bei sumažejusios antikūnų gamybos [20].

Herpes viruso infekcija taip pat gali sukelti epizodini ląstelinị imunodeficitą, paprastai praeinantị savaime [21].

Bakterinès infekcijos dažniausiai ženkliai imuniteto neslopina, tačiau išimtis gali būti bakterijos, išskiriančios toksinus - superantigenus (pvz., stafilokokai, streptokokai). Superantigenai jungiasi su MHC II klasės antigenais bei $\mathrm{T}$ limfocitu receptoriais ir taip stimuliuoja šias ląsteles. Šie limfocitai gamina uždegimo citokinus, dèl to pasireiškia sindromas, panašus ì sepsini šoką (pvz., stafilokokinis toksinio šoko sindromas). Dèl superantigenu poveikio ligos pradžioje cirkuliuojančių $\mathrm{T}$ limfocitų padaugèja, vẻliau ima mažèti. Tyrimai su gyvūnais parodè, kad T limfocitai tampa anergiški ir negali būti pakartotinai aktyvuoti [22].

Mikobakterijos sukelia lètines infekcijas, ji būdinga, kad jos dalijasi fagocitinèse ląstelèse (monocituose ir makrofaguose). Mikobakterijų išskiriami produktai slopina užkrèstos ląstelès gebejjimą perduoti informaciją kitoms imuninėms ląstelėms, o tai gali padidinti antrinių infekcijų riziką [23].

Parazitinès infekcijos taip pat gali veikti imunosupresiškai. Ląstelinis imunitetas pažeidžiamas sergant maliarija, leišmaniozès atveju pažeidžiama fagocitinè funkcija, humoralinị imunitetą gali pažeisti helmintai [24].

\section{APIBENDRINIMAS}

Imuniteto nepakankamumą gali lemti daugelis priežasčiu, todèl gydant kvejpavimo taku infekcijas svarbu ịtarti galimą imuninès sistemos pažeidimą, ypač tais atvejais, kai infekcijos yra dažnos ir linkusios pasikartoti. Svarbu atkreipti dėmesị i tai, kad neretai ir pačios infekcijos, ypač jei jos sunkios, ilgai trunkančios, gali sukelti antrinị imuniteto nepakankamumą ir sąlygoti superinfekciją.

\section{RESPIRATORY TRACT INFECTIONS IN IMMUNODEFICIENCY}

\section{GRETA DVARECKAITE், BRIGITA ŠITKAUSKIENE் \\ DEPARTAMENT OF PULMONOLOGY AND IMMUNOLOGY LITHUANIAN UNIVERSITY OF HEALTH SCIENCES}

Keywords: respiratory infections, immunodeficiency.

Summary. This article discusses the incidence and character of respiratory infections during immunodeficiency.

\section{LITERATŪRA}

1. Marcy TW, Reynolds HY. Pulmonary consequences of congenital and acquired primary immunodeficiency states. Clin Chest Med. 1989; 10(4):503.

2. Šitkauskienè B. Imunodeficitai. KMU leidykla 2006.

3. Esid.org [Internet]. [cited 2012 02] Available from: http://www.esid.org/regis try-number-of-patients

4. Info4pi.org [Internet]. [cited 2012 02]. Available from: www.info4pi.org

5. Bonilla FA, Feldweg AM. Secondary immune deficiency due to miscellane ous causes. [updated 2011, cited 2011 12] available from: http://www.uptodate.com/contents/secondary-immune-deficiency-due-to-miscellaneouscauses? source=search_result\&search=immunodeficiencies\&selectedTitle $=1$ $1 \% 7 \mathrm{E} 150$

6. Naccache JM. Pneumonia in immunocompromised patient. La Revue du praticien. 2011 Oct; 61(8): 1095-101.

7. Pasternack MS, Stiehm ER, Feldweg AM. Approach to the adult with recur rent infections. [cited 2011 11]. Available from: http://www.uptodate.com/ contents/approach-to-the-adult-with-recurrent-infections

8. Rodríguez-Créixems M, Muñoz P, Miranda E, Peláez T, Alonso R, Bouza E. Recurrent pneumococcal bacteremia. A warning of immunodeficiency. Arch Intern Med. 1996;156(13):1429.

9. Marcy TW, Reynolds HY. Pulmonary consequences of congenital and acquired primary immunodeficiency states. Clin Chest Med 1989; 10:503.

10. Cantani A, Ferrara M. The lung and primary immunodeficiency. Allergol Immunopathol. 1988 Nov-Dec; 16(6):429-37.

11. Apisarnthanarak A, Mundy LM. Etiology of community-acquired pneumonia. Clin Chest Med 2005; 26:47.

12. Ballow MJ. Primary immunodeficiency disorders: antibody deficiency. Allergy Clin Immunol. 2002; 109(4): 581.

13. Oksenhendler E, Gérard L, Fieschi $C$, et al. Infections in 252 patients with common variable immunodeficiency. Clin Infect Dis 2008; 46: 1547.

14. Herrod HG. Clinical significance of IgG subclasses. Curr Opin Pediatr. 1993 5(6): 696.

15. [Fishman JA. Infection in solid-organ transplant recipients. $\mathrm{N}$ Engl J Med 2007; 357(25): 2601

16. Saag KG, Koehnke R, Caldwell JR, Brasington R, Burmeister LF, Zimmerman $B$ Kohler JA, Furst DE. Low dose long-term corticosteroid therapy in rheumatoid arthritis: an analysis of serious adverse events. Am J Med. 1994; 96(2): 115.

17. Flannery B, Heffernan RT, Harrison LH, Ray SM, Reingold AL, Hadler J et al. Changes in invasive Pneumococcal disease among HIV-infected adults living in the era of childhood pneumococcal immunization. Ann Intern Med. 2006; 144(1):1.

18. Hull MW, Phillips $P$, Montaner JS. Changing global epidemiology of pulmonary manifestations of HIV/AIDS. Chest. 2008; 134(6): 1287.

19. Morris AM, Huang L, Bacchetti P, Turner J, Hopewell PC, Wallace JM et al. Per manent declines in pulmonary function following pneumonia in human immunodeficiency virus-infected persons. The Pulmonary Complications of HIV Infection Study Group. Am J Respir Crit Care Med. 2000; 162(2 Pt 1): 612.

20. Beckford AP, Kaschula RO, Stephen C. Factors associated with fatal cases of measles. A retrospective autopsy study. S Afr Med J. 1985; 68(12):858.

21. Rinaldo CR Jr. Immune suppression by herpesviruses. Annu Rev Med. 1990 41:331.

22. Langley R, Patel D, Jackson N, Clow F, Fraser JD. Staphylococcal superantigen super-domains in immune evasion Crit Rev Immunol. 2010; 30(2):149.

23. ] Reiner NE. Altered cell signaling and mononuclear phagocyte deactivation during intracellular infection. Immunol Today. 1994; 15(8):374.

24. Dessaint JP, Capron A. Immunodeficiencies in parasitic diseases. Immunodefic Rev. 1989; 1(4):311. 